\title{
Transgenically Targeted Rabies Virus Demonstrates a Major Monosynaptic Projection from Hippocampal Area CA2 to Medial Entorhinal Layer II Neurons
}

\author{
David C. Rowland, ${ }^{1}$ Aldis P. Weible, ${ }^{1}$ Ian R. Wickersham, ${ }^{2}$ Haiyan Wu, ${ }^{1}$ Mark Mayford, ${ }^{3}$ Menno P. Witter, ${ }^{4 \star}$ \\ and Clifford G. Kentros ${ }^{1,4 *}$ \\ ${ }^{1}$ University of Oregon, Institute of Neuroscience, Eugene, Oregon 97403, ${ }^{2}$ Massachusetts Institute of Technology, Department of Brain and Cognitive \\ Sciences, Cambridge, Massachusetts 02139, ${ }^{3}$ The Scripps Research Institute, Department of Cell Biology, La Jolla, California 92037, and ${ }^{4}$ Norwegian \\ University of Science and Technology, Kavli Institute for Systems Neuroscience and Centre for Neural Computation, 7491 Trondheim, Norway
}

The enormous potential of modern molecular neuroanatomical tools lies in their ability to determine the precise connectivity of the neuronal cell types comprising the innate circuitry of the brain. We used transgenically targeted viral tracing to identify the monosynaptic inputs to the projection neurons of layer II of medial entorhinal cortex (MEC-LII) in mice. These neurons are not only major inputs to the hippocampus, the structure most clearly implicated in learning and memory, they also are "grid cells." Here we address the question of what kinds of inputs are specifically targeting these MEC-LII cells. Cell-specific infection of MEC-LII with recombinant rabies virus results in unambiguous labeling of monosynaptic inputs. Furthermore, ratios of labeled neurons in different regions are largely consistent between animals, suggesting that label reflects density of innervation. While the results mostly confirm prior anatomical work, they also reveal a novel major direct input to MEC-LII from hippocampal pyramidal neurons. Interestingly, the vast majority of these direct hippocampal inputs arise not from the major hippocampal subfields of CA1 and CA3, but from area CA2, a region that has historically been thought to merely be a transitional zone between CA3 and CA1. We confirmed this unexpected result using conventional tracing techniques in both rats and mice.

\section{Introduction}

The hippocampal region [dentate gyrus, cornu ammonis (CA) fields, subiculum, entorhinal cortex (EC), presubiculum, and parasubiculum] plays an essential role in the generation of new episodic memories. The canonical hippocampal circuit is largely a unidirectional loop, with neurons in superficial layer II of EC projecting to dentate granule neurons, which in turn project to CA3 pyramidal neurons, which in turn project to CA1 pyramidal neurons. Neurons in CA1 project to deep layers of EC, which close the loop by projecting back to superficial layers of EC.

The precise circuitry of the hippocampal region is of particular interest because in vivo recordings throughout this area in

\footnotetext{
Received March 6, 2013; revised June 17, 2013; accepted July 15, 2013.

Author contributions: D.C.R., A.P.W., M.P.W., and C.G.K. designed research; D.C.R., A.P.W., and H.W. performed research; I.R.W. and M.M. contributed unpublished reagents/analytic tools; D.C.R., A.P.W., and M.P.W. analyzed data; D.C.R., M.P.W., and C.G.K. wrote the paper.

This work was supported by National Institute of Mental Health Grant R21 MH076289, Department of Defense Grant W81XWH-09-2-0114, National Institute of Neurological Disorders and Stroke Grant RC2 NS069464 to C.G.K., and Norwegian Research Council Grants 145993 and 81676 and the Kavli Foundation to M.P.W. We thank H. Sebastian Seung for providing the rabies virus.

The authors declare no competing financial interests.

${ }^{*}$ M.P.W. and C.G.K. contributed equally to this work.

This article is freely available online through the J Neurosci Author Open Choice option.

Correspondence should be addressed to Dr. Clifford Kentros, Kavli Institute for Systems Neuroscience and Centre

for Neural Computation, Norwegian University of Science and Technology, NTNU, PO Box 8905, 7491 Trondheim, Norway. E-mail: clifford.kentros@ntnu.no.

DOI:10.1523/JNEUROSCI.1046-13.2013

Copyright $\odot 2013$ the authors $\quad 0270-6474 / 13 / 3314889-10 \$ 15.00 / 0$
}

behaving rodents have revealed a set of distinct cell types that represent position, environmental geometry, and direction (McNaughton et al., 2006). These properties suggest that the neurons within the hippocampal region participate in forming a mental map of an environment, consistent with a role in spatial memory. Four key cell types have been described in this broad neural circuit: place cells, grid cells, border cells, and head direction cells (O'Keefe, 1976; Taube et al., 1990; Hafting et al., 2005; Solstad et al., 2008). This raises questions about how and where the cellspecific activity patterns are generated and the degree of interdependence between them. One recent study found that inactivation of the hippocampus leads to an extinction of the grid pattern (Bonnevie et al., 2013), indicating that excitatory drive from the hippocampus is required for the expression of grid patterns in medial EC (MEC). Since the stellate cells of layer II of the MEC (MEC-LII) are candidate grid cells (Burgalossi et al., 2011; Couey et al., 2013; Schmidt-Hieber and Hausser, 2013), such hippocampal excitation needs to reach the stellate cells. The current circuit model predicts that there is at least one synapse in layer $\mathrm{V}$ in between the $\mathrm{CA}$ field and the stellate targets (Witter, 2012). A weak direct projection from CA1 has been postulated to reach layer II (Cenquizca and Swanson, 2007), but the postsynaptic targets have not been identified, largely because it is extremely difficult to determine connectivity with cellular resolution using traditional neuroanatomical tools.

We therefore generated transgenic mice that restrict the infection of EnvA-pseudotyped, glycoprotein (G)-deleted recom- 

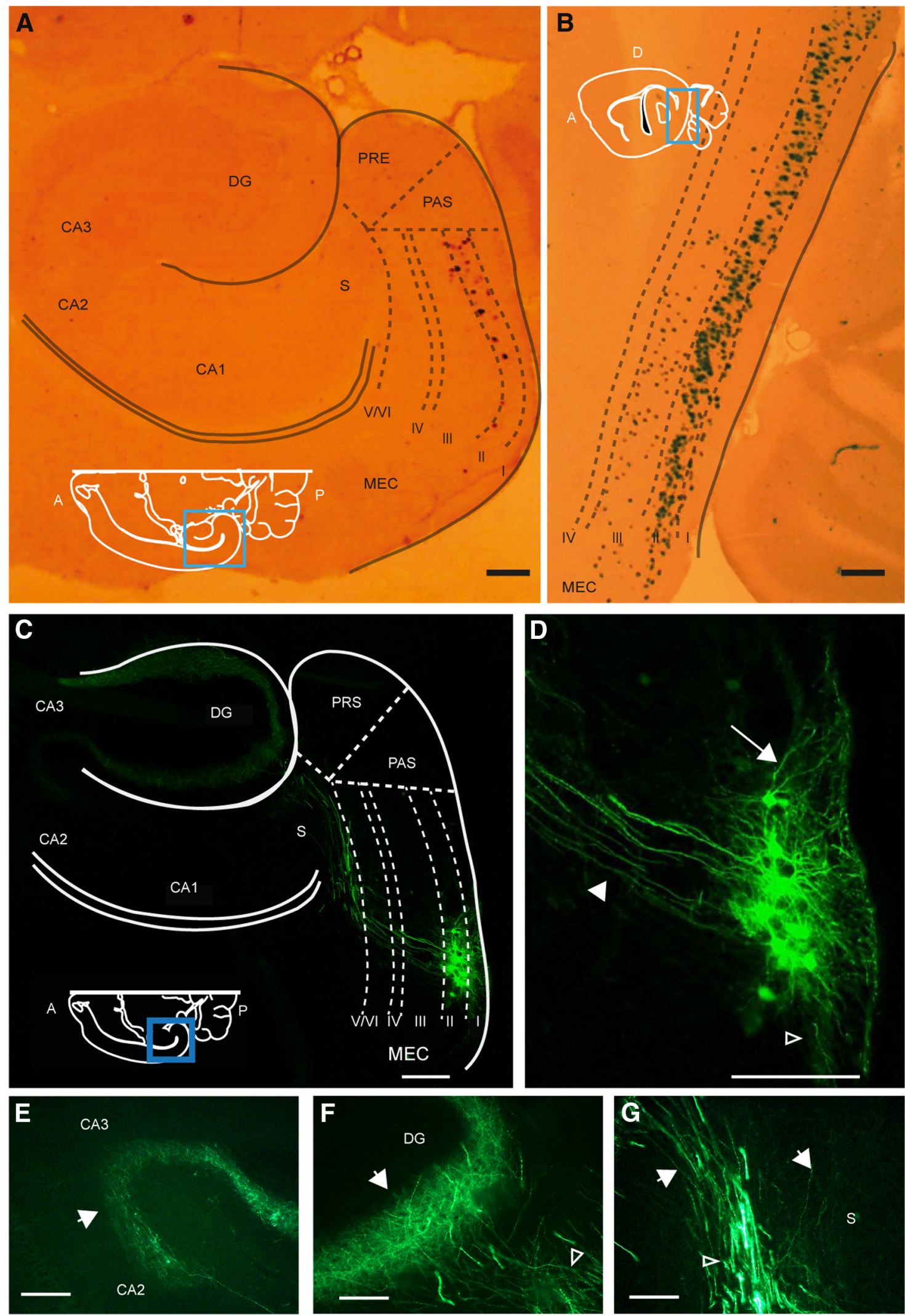

Figure 1. TVAG expression is almost exclusively restricted to neurons in MEC-LII. $\boldsymbol{A}, \boldsymbol{B}$, In situ hybridization for the TVA receptor in an EC $\times$ TVAG-7 animal $(\boldsymbol{A})$ in the horizontal plane and an EC $\times$ TVAG-5 animal (B) in the sagittal plane. $\boldsymbol{C}$, The injection of a large volume (150 nl) of [LV-CMVP-eGFP(EnvA)] lentivirus into the superficial layers of the dorsal MEC of an EC $\times$ TVAG-7 mouse straddled MEC-LII/III border, yet only a small group of MEC-LII projection neurons were infected. $\boldsymbol{D}$, The neurons were primarily stellate-shaped with thick primary axons (filled arrowhead), superficially branching dendrites (arrow), and axon collaterals (open arrowhead). $\boldsymbol{E}, \boldsymbol{F}$, Dense axon terminations were found in the dentate gyrus (DG), CA3, and CA2 regions. $\boldsymbol{G}$, Sparse axon terminations were also found in the subiculum. $E-G$, Arrows indicate axon termination sites and open arrowheads indicate passing fibers. $A, C$, Insets, The plane and level of section and where the image has been obtained. Scale bars: $A, 300 \mu \mathrm{m} ; \boldsymbol{B}, 200 \mu \mathrm{m} ; C, D, 250 \mu \mathrm{m} ; E-G, 100 \mu \mathrm{m}$. A, Anterior; LEC, lateral EC; P, posterior; PAS, parasubiculum; PRS, presubiculum; $S$, subiculum. 
binant rabies virus to MEC-LII, where grid cells are the predominant cell type (Sargolini et al., 2006; Boccara et al., 2010). Once inside the cell, the fluorescent signal is amplified by viral replication of the rabies virus, providing bright labeling of the cells for accurate cell counting, but the resulting virions are only infectious when complemented with G. Since the transgenic mice only express TVA (the EnvA receptor) and G almost exclusively in MEC-LII cells, viral injections only label MEC-LII neurons and their monosynaptic inputs. Our results reveal a previously unknown major input to MEC-LII neurons from the CA2 region of the hippocampus, thus providing a direct excitatory monosynaptic hippocampal feedback to this major hippocampal input.

\section{Materials and Methods}

Virus production. EnvA-pseudotyped lentivirus was generated as previously described (Wickersham et al., 2007a), with the exception that the rabies virus glycoprotein expression vector was omitted from the transfection and the plasmid pCMMP-EnvARGCD-IRES-EGFP (Wickersham et al., 2007b) encoding the EnvA envelope glycoprotein with the cytoplasmic domain of the rabies virus glycoprotein was included instead. G-deleted rabies viral vectors encoding TagRFP-T (Shaner et al., 2008) and mTagBFP (Subach et al., 2008) were created by cloning these genes into the genome plasmid cSPBN-4GFP (Wickersham et al., 2010) to make the plasmids $\mathrm{pRV}-4 \mathrm{RFP}$ and $\mathrm{pRV}-4 \mathrm{BFP}$ before proceeding with EnvA-pseudotyped rabies virus production as described previously (Wickersham et al., 2010). G-deleted rabies viral vectors encoding GFP were made as previously described (Weible et al., 2010). All viruses were purified by ultracentrifugation through $20 \%$ sucrose and titered on HEK-293T or 293T-TVA800 cells as described previously (Wickersham et al., 2010).

Subjects and injections. All procedures described were performed in accordance with guidelines approved by University of Oregon's Animal Care and Use Committee and the National Institutes of Health Guide for the Care and Use of Laboratory Animals (National Institutes of Health Publications No. 80-23).

The mice were generated by crossing TVAG-tetO lines that we generated (Weible et al., 2010) to an existing tTA line (Yasuda and Mayford, 2006). For the present study, we used three of the TVAG lines developed by Weible and colleagues (Weible et al., 2010): TVAG-4, TVAG-5, and TVAG-7. A total of 18 double-transgenic mice were injected with virus in the present study. To visualize the first-order neurons, four of these mice received the EnvA-pseudotyped lentivirus [LV-CMVP-eGFP(EnvA)], which does not travel across synapses. To examine monosynaptic inputs, the remaining 14 received the $\Delta G$ rabies virus.

All surgeries were performed using aseptic techniques. Mice were anesthetized with a mixture of ketamine $(100 \mathrm{mg} / \mathrm{kg})$ and dexmedetomidine hydrochloride $(40 \mu \mathrm{g} / \mathrm{kg})$. Dexamethasone $(0.1 \mathrm{mg} / \mathrm{kg})$ and atropine $(0.03 \mathrm{mg} / \mathrm{kg})$ were administered presurgically to ameliorate possible inflammation and respiratory irregularities, respectively. For injections, a single hole was drilled in the skull above either MEC (3.0 mm lateral to the midline and $0.5 \mathrm{~mm}$ anterior to the transverse sinus) or parasubiculum $(2.0 \mathrm{~mm}$ lateral to the midline and $0.5 \mathrm{~mm}$ anterior to the transverse sinus). A $500 \mathrm{nl}, 33$ gauge Hamilton syringe loaded with $200 \mathrm{nl}$ of the virus solution was attached to a stereotaxic frame (Kopf Instruments). The syringe was then lowered at $500 \mu \mathrm{m}$ increments, resting $2 \mathrm{~min}$ between increments, to a resting depth of $1.4 \mathrm{~mm}$ for dorsal or $2.5 \mathrm{~mm}$ for ventral injections. The syringe was maintained at this depth for $5 \mathrm{~min}$ before injection to allow the tissue to settle. Injections of rabies virus or lentivirus were made in $10 \mathrm{nl}$ steps, pausing 1 min between steps. For rabies virus, the total injected volume was $25-200 \mathrm{nl}$. For Fast Blue (1\% in PBS; EMS-Chemie) and lentivirus, the total injected volume was $100-$ $200 \mathrm{nl}$. The syringe was maintained at depth for $15 \mathrm{~min}$ after the full volume was injected, then raised $200 \mu \mathrm{m}$ and kept there for an additional $5 \mathrm{~min}$ before removal. Mice were administered buprenorphine $(0.06$ $\mathrm{mg} / \mathrm{kg}$ ) for postoperative analgesia, and individually housed following surgery.

The additional data in two rats were obtained from a large database of available experiments performed in female Wistar rats and procedures
Table 1. Counts of transgenic neurons from the three lines ${ }^{a}$

\begin{tabular}{llllll}
\hline & $\begin{array}{l}\text { MEC-LII } \\
\text { (cells/ } \\
\text { hemisphere) }\end{array}$ & $\begin{array}{l}\text { MEC-LIII } \\
\text { (cells/ } \\
\text { hemisphere) }\end{array}$ & $\begin{array}{l}\text { Lateral EC } \\
\text { (cells/ } \\
\text { hemisphere) }\end{array}$ & $\begin{array}{l}\text { Parasubiculum } \\
\text { (cells/ } \\
\text { hemisphere) }\end{array}$ & $\begin{array}{l}\text { Presubiculum } \\
\text { (cells/ } \\
\text { hemisphere) }\end{array}$ \\
\hline EC $\times$ TVAG-5 5 & 7535 & 905 & 265 & 2260 & 45 \\
EC X TVAG-7 & 1065 & 0 & 0 & 0 & 0 \\
EC $\times$ TVAG-4 & 102 & 0 & 0 & 0 & 0 \\
\hline
\end{tabular}

$\bar{a}$ In situ positive neurons were counted across regions and layers for one animal from each cross. Counts were zero in all unlisted regions.

(Kononenko and Witter, 2012), largely similar to those described for mice below, were performed according to national and European regulations.

Histology and tissue processing. Seven days following injection, mice were killed with a lethal dose of sodium pentobarbital $(50 \mathrm{mg} / \mathrm{kg})$ and perfused transcardially with freshly made $4 \%$ paraformaldehyde in PBS. Following removal, brains were postfixed in the perfusion solution overnight at $4^{\circ} \mathrm{C}$ and then kept in $30 \%$ sucrose at $4^{\circ} \mathrm{C}$ for $16-24 \mathrm{~h}$. Brains were cryostat-sectioned at $30 \mu \mathrm{m}$, mounted onto microscope slides, and airdried. The tissue was collected in a set of five (for sagittal) or six (for horizontal) series such that each series contained equally spaced sections across the entire axis of sectioning. Each series contained between 20 and 26 sections. All sections were kept at room temperature for $24 \mathrm{~h}$, then either processed with nonradioactive in situ hybridization (ISH) for TVA mRNA expression or stored at $-80^{\circ} \mathrm{C}$ for later visualization of florescent label or antibody staining. ISH was performed as previously described (Weible et al., 2010).

For antibody staining, the sections were washed with $1 \times$ PBS three times for $10 \mathrm{~min}$, rinsed with PBT (PBS plus $0.3 \%$ Triton X-100), blocked with PBT plus $10 \%$ NGS for $3 \mathrm{~h}$ at room temperature, and finally incubated with the primary antibody for GAD67 (mouse anti-GAD67, Millipore) or parvalbumin (mouse anti-parvalbumin, Millipore). The next day, the slides were washed with PBT four times for $10 \mathrm{~min}$, incubated with the secondary antibody [Alexa Fluor 488 goat anti-mouse IgG $(\mathrm{H}+\mathrm{L})$, Invitrogen] for $4 \mathrm{~h}$ at room temperature, and finally washed with PBT four times for $10 \mathrm{~min}$ and covered with a coverslip.

For figures, some slides were incubated in ScaleA2 (Hama et al., 2011). This step improved the signal-to-noise ratio but was not necessary for visualizing labeled cells. Also for the figures, schematic drawings were modified from Adobe Illustrator (Adobe Systems) line drawings provided by Paxinos and Watson (2007) or Paxinos and Franklin (2001).

Microscopy and photomicrography. Sections were viewed using an Olympus (BX61) microscope. Rabies virus-expressed TagRFP-T was visualized with a DsRed filter (Chroma part \#U-N42005). eGFP was visualized with a FITC filter and mTagBFP was visualized with a DAPI filter. The FITC and DAPI filters were part of the same Pinkel filter set (Semrock part \#DA/FI/TX-3X-A-000). Slides were scanned at $10 \times$ magnification and the images stored at high resolution for cataloging and cell counting. Additional images of important regions were taken at $20 \times$ magnification.

To quantify the number of the in situ positive neurons or labeled cells following rabies injection, a representative series was chosen and the number of cells from that entire series was manually counted in each hemisphere. The counted cells were sorted by region and, when appropriate, layer. Since we made injections either in dorsal or ventral MEC, we additionally separated the results for dorsal and ventral injections, regardless of transgenic line. These counts were then multiplied by the number of skipped sections ( 5 for sagittal and 6 for horizontal) to estimate the total number of labeled cells in that hemisphere. For rabies injections, only neurons outside of layer II were counted, because within layer II it is impossible to distinguish primary versus secondary infections. Finally, we also saw some occasional labeling of cells in white matter (see Fig. $3 \mathrm{~A}$, in the perforant path). Based upon their morphology and exclusive incidence in white matter, we reasoned that these cells are oligodendrocytes, as previously reported for wild-type rabies infection (Feiden et al., 1988), and did not count them as neurons. All other cells that were counted had morphologies that were clearly neuronal. 

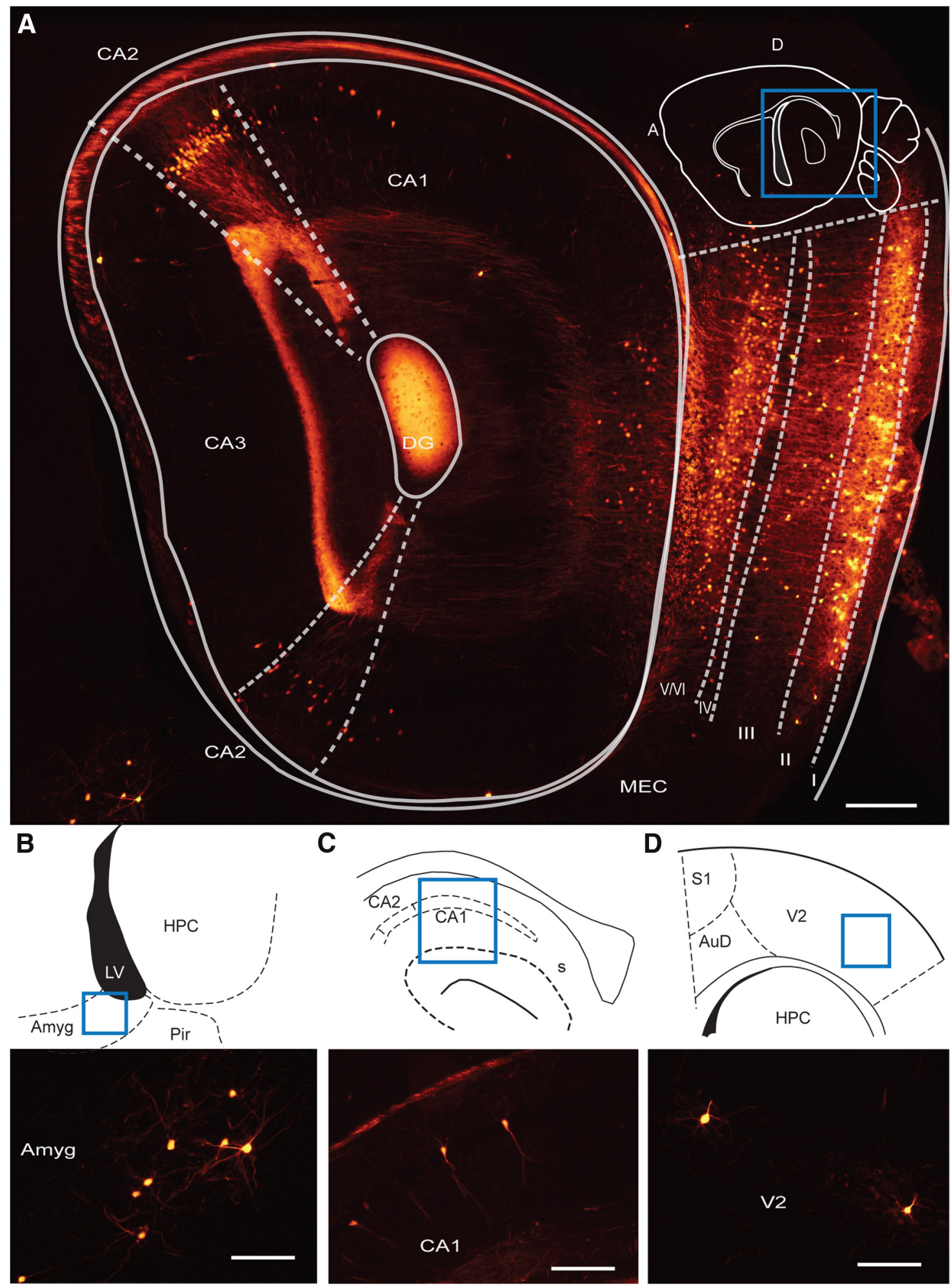

Figure 2. Retrograde transport of the modified rabies virus in an EC $\times$ TVAG-5 animal. $A$, Large numbers of labeled neurons were found in CA2 and all cell layers of MEC following injection of the modified rabies virus into the dorsal MEC. The schematic in $A$ gives the plane and level of section. The bright label in CA3 and dentate gyrus (DG) represents the terminations of labeled axons of perforant path projecting neurons. $\boldsymbol{B}-\boldsymbol{D}$, Fewer labeled neurons were found in the amygdala $(\boldsymbol{B}), C A 1(\boldsymbol{C})$, and layer II/III of V2 (D). Schematics above the images in $\boldsymbol{B}-\boldsymbol{D}$ give the location of each image. Scale bars: $\boldsymbol{A}, 250 \mu \mathrm{m} ; \boldsymbol{B}-\boldsymbol{D}, 100 \mu \mathrm{m}$. A, Anterior; Amyg, amygdala; AuD, secondary auditory cortex; D, dorsal; LV, lateral ventricle; PiR, piriform cortex; S, subiculum; S1, primary somatosensory cortex; $\mathrm{V} 2$, secondary visual cortex.

\section{Results}

A genetic system for mapping inputs to MEC-LII

The rabies-based monosynaptic retrograde tracing system developed by Wickersham and colleagues (Wickersham et al., 2007a,b) requires an avian receptor (TVA) for initial infection and the rabies glycoprotein $(\mathrm{G})$ for subsequent trans-synaptic infection. Our recently developed tetO-TVAG lines (Weible et al., 2010) supply both proteins transgenically via the tetO/tTA 


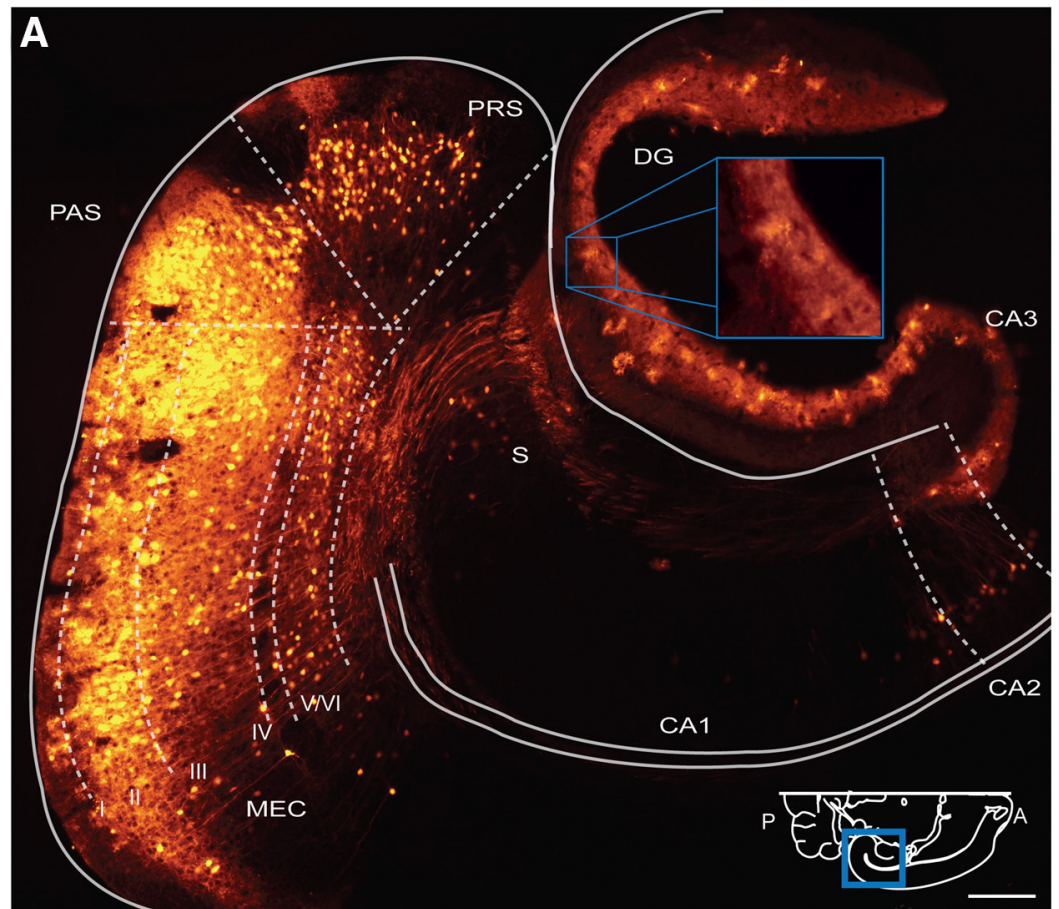

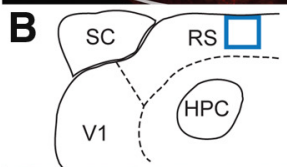
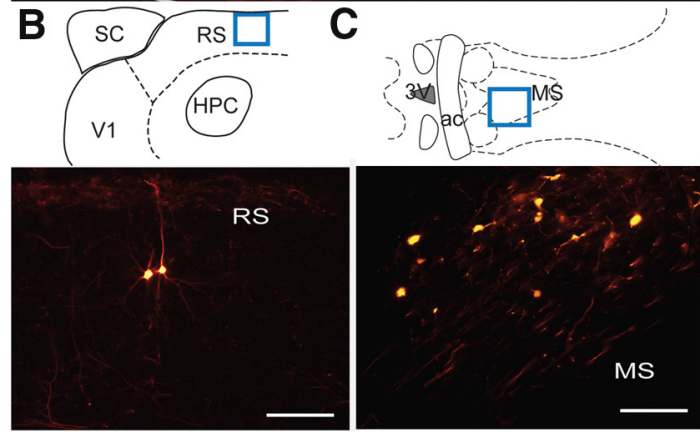

D
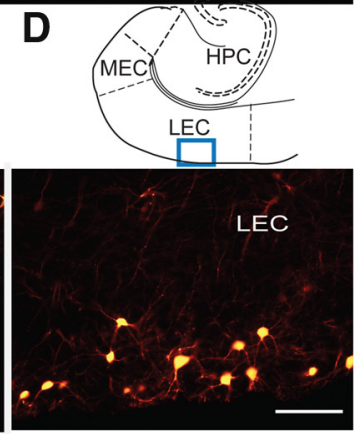

Figure 3. Retrograde transport of the modified rabies virus in an $\mathrm{EC} \times \mathrm{TVAG}-7$ animal. $A$, Large numbers of neurons were found in CA2, all cell layers of MEC, PaS, and PrS. The schematic in $A$ gives the plane and level of section. The bright label in $C A 3$ and dentate gyrus (DG) represents the terminations of labeled axons of perforant path projecting neurons. These terminations are expanded in the inset. $\boldsymbol{B}-\boldsymbol{D}$, Fewer neurons were found in layer II/III of the retrosplenial cortex $(\boldsymbol{B})$, medial septum $(\boldsymbol{C}$, and layer II of the lateral EC ( $\boldsymbol{D}$ ). Images were taken from different sections of the same horizontal series. Schematics above the images in $\boldsymbol{B}-\boldsymbol{D}$ give the location of each image (schematics modified from Paxinos and Franklin, 2001). Scale bars: $\boldsymbol{A}, 250 \mu \mathrm{m} ; \boldsymbol{B}-\boldsymbol{D}, 100 \mu \mathrm{m}$. 3V, Third ventricle; $A$, anterior; ac, anterior commissure; $H P C$, hippocampus; LEC, lateral EC; MS, medial septum; $P$, posterior; PAS, parasubiculum, $\mathrm{PRS}$, presubiculum; $\mathrm{RS}$, retrosplenial cortex; $\mathrm{S}$, subiculum; $\mathrm{SC}$, superior coliculus; $\mathrm{V1}$, primary visual cortex.

system (Mansuy and Bujard, 2000). In our prior study (Weible et al., 2010), injecting tTA-negative, TVAG-positive animals from these lines with virus resulted in no infection, demonstrating the absolute requirement for transgene expression. Mating the ECtTA driver line (Yasuda and Mayford, 2006) to tetO-TVAG lines yields expression of TVA and G almost exclusively in MEC-LII (Fig. 1), enabling us to target the initial infection of injected rabies virus specifically to MEC-LII neurons. For this study, we used three tetO-TVAG lines (TVAG-4, TVAG-5, and TVAG-7), each providing the requisite TVA and $\mathrm{G}$ at different densities due to insertional effects (Table 1). These same insertional effects likely account for why our crosses yielded more specific expression than that initially reported for the tTA line (Yasuda and Mayford, 2006), with two of the three crosses expressing exclusively in MEC-LII. Since any virus pseudotyped with the viral protein EnvA can infect the transgenic neurons, we first used a GFPlabeled lentivirus [LV-CMVP-eGFP(EnvA)] incapable of crossing synaptic contacts to visualize the first-order transgenic neurons. We then used EnvA-pseudotyped G-deleted rabies virus to visualize the monosynaptic inputs to these transgenic entorhinal layer II neurons.

Characterization of transgenic neurons ISH for TVA receptor mRNA (Fig. 1) and subsequent cell counting revealed that each cross had distinct densities of expression ranging from $<100$ MEC-LII cells in EC $\times$ TVAG- 4 to $\sim 7000$ MEC-LII cells in $\mathrm{EC} \times$ TVAG-5. The EC $\times$ TVAG-5 line also contained a smaller number of positive cells in the presubiculum and parasubiculum (Table 1). We labeled cells expressing the receptor from each cross with 100 or $150 \mathrm{nl}$ of lentivirus [LVCMVP-eGFP(EnvA)]. Regardless of the precise location and volume injected, just a small cluster of cells in MEC-LII was labeled, demonstrating the specificity of expression (Fig. 1C). The soma, axons, and dendrites were all brightly labeled, allowing clear visualization of the cellular morphology and their axonal targets (Fig. 1D$G)$. The labeled cells have all of the morphological characteristics of stellate cells, a major principal cell in MEC-LII (Lorente de Nó, 1933; Canto and Witter, 2012). In this example, a densely labeled terminal axonal plexus could be seen in the molecular layer of the dentate gyrus that extended through CA3. A weaker though still clearly labeled projection terminates in the subiculum, likely representing local collaterals from perforating layer II axons (Tamamaki and Nojyo, 1993). The terminations were limited to the dorsal hippocampus, consistent with the known topography of projections from MEC to the hippocampus (Witter, 2012). By taking the number of in situ positive neurons in MEC-LII and dividing by the approximate of number of stellate cells in MEC-LII of mice (Gatome et al., 2010), we estimated that the density of expression in MEC-LII stellate cells was $47 \%$ in the EC $\times$ TVAG-5, $6 \%$ in EC $\times$ TVAG-7, and $<1 \%$ in $\mathrm{EC} \times \mathrm{TVAG}-4$ line.

\section{Retrograde tracing reveals a major input from CA2}

To examine the inputs to MEC-LII neurons, we injected $14 \mathrm{EC} \times$ TVAG mice with 25-200 $\mathrm{nl}$ of the $\Delta G$ rabies virus into either the dorsal or ventral MEC. The injections were $>1 \mathrm{~mm}$ lateral to the parasubiculum, thus lessening the likelihood of infection in the parasubiculum in the TVAG-5 line, where we observed some lighter expression of the transgene. Animals were injected bilaterally ( 1 site per hemisphere) but with different colored fluorophores in each hemisphere [typically RFP in 1 hemisphere and GFP or blue fluorescent protein (BFP) in the other]. The uptake and transport of the virus resulted in labeled cells both locally and several millimeters away (Figs. 2-4) and strongly labeled axons of both first-order and second-order neurons in the perforant pathway, the hippocampal commissure, and the fornix. Labeled ax- 

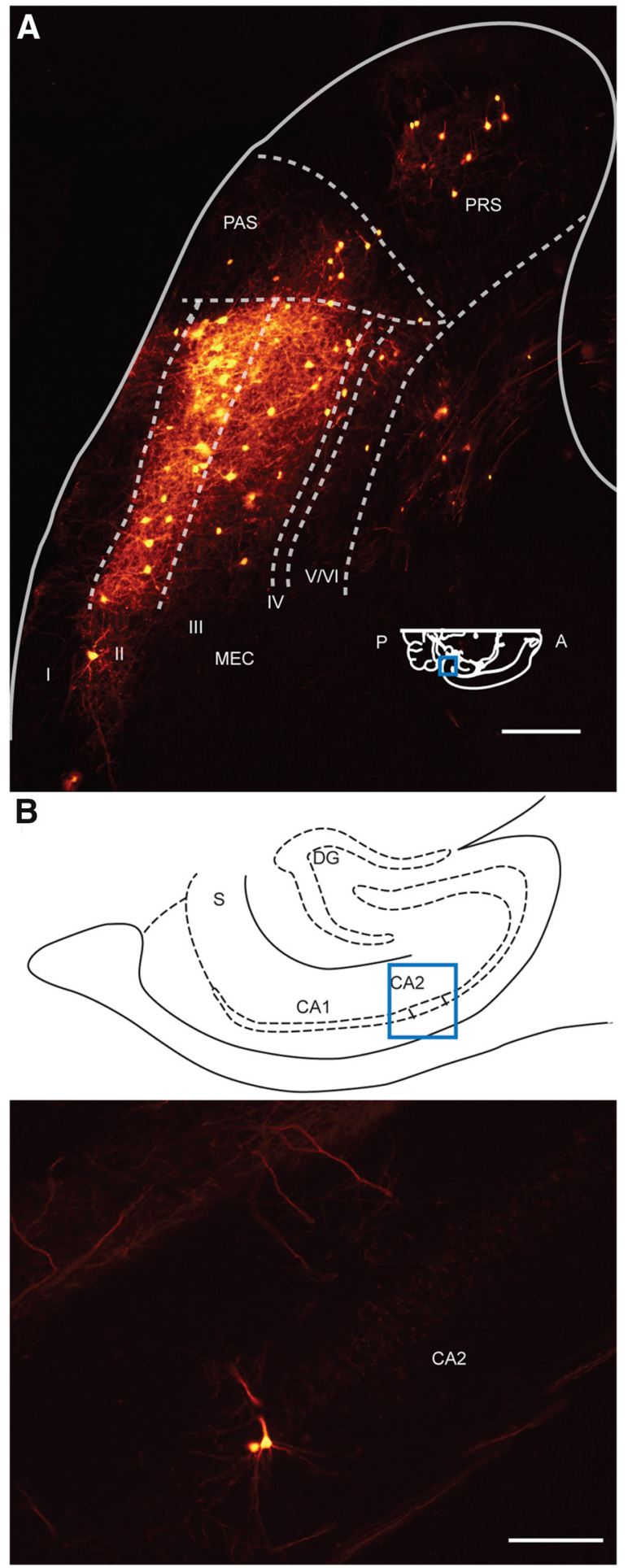

Figure 4. Retrograde transport of the modified rabies virus in a sparsely expressing $E C X$ TVAG-4 animal. $A, B$, The sparse retrograde labeling observed was concentrated predominantly in the MEC, parasubiculum (PAS), presubiculum (PRS; $\boldsymbol{A})$, and CA2 $(\boldsymbol{B})$. The inset in $\boldsymbol{A}$ gives the plane and level of section. The images in $\boldsymbol{A}$ and $\boldsymbol{B}$ were taken from different sections of the same horizontal series. The schematic above the images in $\boldsymbol{B}$ gives the location of the CA2 image (schematic modified from Paxinos and Franklin, 2001). Scale bars: $\boldsymbol{A}, 250 \mu \mathrm{m} ; \mathrm{A}$, anterior; $\mathrm{P}$, posterior; S, subiculum.

ons, particularly those traveling in the perforant pathway, also showed dense terminal fields in their expected target areas in the molecular layer of the dentate gyrus and stratum lacunosum moleculare of CA3 (Fig. 3A). We observed large numbers of labeled cells in layer III of the presubiculum, all layers of parasubiculum, and all layers of the MEC, as expected (van Groen and Wyss, 1990; van Haeften et al., 2003; van Strien et al., 2009; Beed et al., 2010; Kononenko and Witter, 2012). Fewer cells were seen in the amygdala, layer II of the lateral EC, subiculum, CA1, postrhinal cortex, layer II/III of V2, and layer II/III of the retrosplenial cortex (Cenquizca and Swanson, 2007; Jones and Witter, 2007; Kerr et al., 2007). Somewhat surprisingly, the patterns were similar for both dorsal and ventral injections (Table 2). However, due to the potent nature of the virus and the possibility of wicking up the track, one can never be certain how well the virus was restricted to the injected area. Most of our results thus confirmed previous work.

In addition to these expected regions, however, we also observed large numbers of labeled cells in the CA2 region of the hippocampus (Figs. 2, 3). CA2 label was even present in the most restrictive EC $\times$ TVAG-4 line (Fig. 4). Although these data are inconsistent with all recent reports, Lorente de Nó (1934) did note that CA2 pyramidal neurons send an axon toward the EC, but he did not identify the precise target of the projection.

One of our transgenic lines (TVAG-5) exhibited some label in the presubiculum and parasubiculum, potentially confounding our results. To control for the possibility that the virus spread into the presubiculum or parasubiculum in these animals, we injected three EC $\times$ TVAG-5 mice with the $\Delta G$ rabies virus directly into the presubiculum and parasubiculum. We observed no CA2 label in these animals (Fig. 5) except in one case where the injection was on the border of MEC and likely infected MEC neurons as well (there were labeled MEC-LII neurons near the injection site, but it is impossible to tell whether they were primary or secondary infection). Together, these data strongly support our claim of a direct projection from CA2 to MEC-LII. Judging by morphology, localization within stratum pyramidale, and immunohistochemistry of rabies-injected brains with antisera to both parvalbumin and GAD67 (data not shown), it is highly likely that this direct projection is excitatory in nature.

We also sought to confirm the CA2 label with an unrelated technique. Using coordinates similar to those of the viral injections, we injected Fast Blue, a conventional retrograde tracer, bilaterally into the MEC of eight mice. Of the nine injections that were centered in the superficial layers of MEC and did not involve presubiculum and parasubiculum, five showed clear CA2 label (Fig. 6). Unlike the rabies virus, the Fast Blue injections were not specific to layer II and likely spread across all layers, accounting for the very strong label we observed in CA1 following these injections. The remaining four injections that did not show CA2 label were located more lateral or ventral within MEC, suggesting that the input from CA2 may be strongest in the dorsomedial sector of MEC. Since a direct projection from CA2 to layer II of MEC has not been reported before in rats, our findings may be specific for mice. Injection of the anterograde tracer biotinylated dextran amine specifically into area CA2 in two rats, however, is consistent with a similar projection in rats (Fig. 7). In line with the mouse data, the anterogradely labeled fibers were confined to the dorsomedial domain of MEC, such that in coronal sections they were only visible in what is essentially the most posterior section possible. This may explain why the projection has been missed in previous analyses. Our observations thus also suggest that there may be functional differences in connectivity between subregions of MEC. 
Table 2. Quantification of rabies labeled cells by structure ${ }^{a}$

\begin{tabular}{|c|c|c|c|c|c|c|}
\hline & $\begin{array}{l}\text { EC } \times \text { TVAG-4 } \\
\text { (percentage; range) }\end{array}$ & $\begin{array}{l}\text { EC } \times \text { TVAG-5 } \\
\text { (percentage; range) }\end{array}$ & $\begin{array}{l}\text { EC } \times \text { TVAG-7 } \\
\text { (percentage; range) }\end{array}$ & $\begin{array}{l}\text { Dorsal } \\
\text { (percentage; range) }\end{array}$ & $\begin{array}{l}\text { Ventral } \\
\text { (percentage; range) }\end{array}$ & $\begin{array}{l}\text { Overall } \\
\text { (percentage; rank) }\end{array}$ \\
\hline \multicolumn{7}{|l|}{ Parahippocampal region } \\
\hline MEC-LIII & $26.79 ; 19.29-34.29$ & $12.96 ; 11.60-14.02$ & $17.27 ; 16.35-18.15$ & $21.83 ; 16.35-34.29$ & $15.07 ; 11.60-19.29$ & $19.00 ; 2$ \\
\hline MEC-LV & $13.06 ; 17.54-8.57$ & $24.75 ; 20.28-28.63$ & $13.07 ; 9.62-16.90$ & $11.95 ; 8.57-16.90$ & $22.35 ; 17.54-29.00$ & $16.96 ; 4$ \\
\hline LEC & $0 ; 0-0$ & $2.59 ; 0.09-5.04$ & $2.75 ; 0.9-4.77$ & $2.77 ; 0.92-4.77$ & $2.59 ; 0-5.09$ & $1.78 ; 8$ \\
\hline $\mathrm{PaS}$ & $25.36 ; 19.30-31.43$ & $27.18 ; 20.89-20.98$ & $13.3 ; 7.65-24.85$ & $17.87 ; 7.64-31.43$ & $20.55 ; 19.29-21.25$ & $21.95 ; 1$ \\
\hline PrS & $20.95 ; 8.57-33.33$ & $8.86 ; 5.17-12.38$ & $24.20 ; 15.09-30.57$ & $20.29 ; 8.57-30.57$ & $17.02 ; 5.17-33.33$ & $18.00 ; 3$ \\
\hline \multicolumn{7}{|l|}{ Hippocampal formation } \\
\hline CA1 & $0 ; 0-0$ & $1.75 ; 2.83-3.51$ & $6.53 ; 3.49-8.3$ & $4.90 ; 0-8.3$ & $3.31 ; 2.87-3.50$ & $2.76 ; 7$ \\
\hline CA2 & $6.37 ; 5.71-7.01$ & $18.69 ; 16.77-20.18$ & $10.82 ; 8.12-12.5$ & $9.55 ; 5.71-11.86$ & $14.80 ; 7.02-20.18$ & $11.96 ; 5$ \\
\hline $\mathrm{CA} 3$ & $0 ; 0-0$ & $0.10 ; 0.09-0.10$ & $0 ; 0-0$ & $0 ; 0-0$ & $0.06 ; 0-0.09$ & $0.03 ; 17$ \\
\hline Sub & $4.29 ; 0-8.57$ & $3.35 ; 0.43-6.20$ & $3.76 ; 2.99-5.10$ & $4.96 ; 2.99-8.57$ & $2.23 ; 0-6.20$ & $3.80 ; 6$ \\
\hline \multicolumn{7}{|l|}{ Other } \\
\hline POR & $0 ; 0-0$ & $1.13 ; 0.99-1.28$ & $3.91 ; 2.16-5.65$ & $2.63 ; 0-5.65$ & $0.76 ; 0-1.28$ & $1.68 ; 9$ \\
\hline V2 & $0 ; 0-0$ & $0.32 ; 0.09-0.54$ & $0.04 ; 0-0.07$ & $0.04 ; 0-0.09$ & $0.32 ; 0.08-0.54$ & $0.12 ; 12$ \\
\hline Amyg & $0 ; 0-0$ & $0.22 ; 0-0.44$ & $0.09 ; 0-0.15$ & $0.06 ; 0-0.15$ & $0.14 ; 0-0.44$ & $0.10 ; 13$ \\
\hline MS/DBB & $0 ; 0-0$ & $1.04 ; 0.08-1.98$ & $2.47 ; 0.26-5.38$ & $1.85 ; 0-5.38$ & $0.70 ; 0-2.00$ & $1.17 ; 10$ \\
\hline Raphe & $0 ; 0-0$ & $0 ; 0-0$ & $0.26 ; 0-0.61$ & $0 ; 0-0$ & $0.39 ; 0-0.61$ & $0.09 ; 14$ \\
\hline RS & $0 ; 0-0$ & $0 ; 0-0$ & $0.20 ; 0.07-0.33$ & $0.02 ; 0-0.07$ & $0.11 ; 0-0.33$ & $0.07 ; 15$ \\
\hline AUD & $0 ; 0-0$ & $0.58 ; 0.52-0.64$ & $1.52 ; 0-2.49$ & $1.14 ; 0-2.5$ & $0.39 ; 0-0.64$ & $0.7 ; 11$ \\
\hline Claustrum & $0 ; 0-0$ & $0 ; 0-0$ & $0.04 ; 0-0$ & $0.03 ; 0-0.11$ & $0 ; 0-0$ & $0.04 ; 16$ \\
\hline Average number labeled neurons & 438 & 15,965 & 10,415 & & & \\
\hline
\end{tabular}

${ }^{a}$ A percentage was calculated by dividing the number of rabies labeled cells for each region by the overall label excluding MEC-LII, thus giving an estimate of the strength of the projection to MEC-LII. Note that the labeled cells were found in the major inputs (including $(\mathrm{A} 2$ ) in every rabies-injected animal as indicated by the ranges. Percentages following dorsal and ventral injections were pooled across all animals regardless of transgenic line.

MEC-LV, Layer V of MEC; LEC, lateral EC; PaS, parasubiculum; PrS, presubiculum; Sub, subiculum; POR, postrhinal cortex; Amyg, amygdala; MS/DBB, medial septum/diagonal band of Broca; RS, retrosplenial cortex; AUD, secondary auditory cortex.

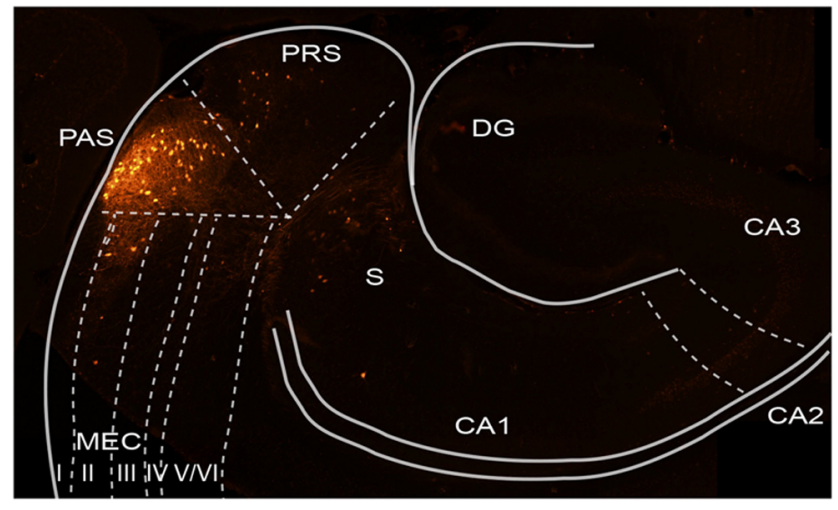

Figure 5. Lack of CA2 label following injection of modified rabies virus directly into presubiculum (PRS) and parasubiculum (PAS). An example injection targeted directly to the border of the presubiculum and parasubiculum of an EC $\times$ TVAG- 5 animal resulted in infection of presubiculum and parasubiculum. № CA2 label was observed in this or other sections. Scale bar, $250 \mu \mathrm{m}$. S, Subiculum.

\section{Cell counting}

The bright and robust label produced by the rabies virus allowed for unambiguous identification of neurons. We therefore counted cells in animals injected with the $\Delta G$ rabies virus and generated a quantitative profile of inputs to MEC-LII. We manually counted across brain regions and, when appropriate, layers or subregions for one series and multiplied by the number of skipped series to give an estimate of the total number of labeled cells in that region, layer, or subregion for seven animals injected with 100-200 $\mathrm{nl}$ of RFP-labeled virus. The regions were defined using boundaries of a recent mouse nervous system atlas (Witter, 2012). In particular, the atlas defines the CA2 region based on a combination of morphological characteristics, such as where the mossy fibers bend ventrally to form the "end bulb," and protein expression, such as parvalbumin. This provides a conservative estimate of the borders of CA2, since gene expression patterns,

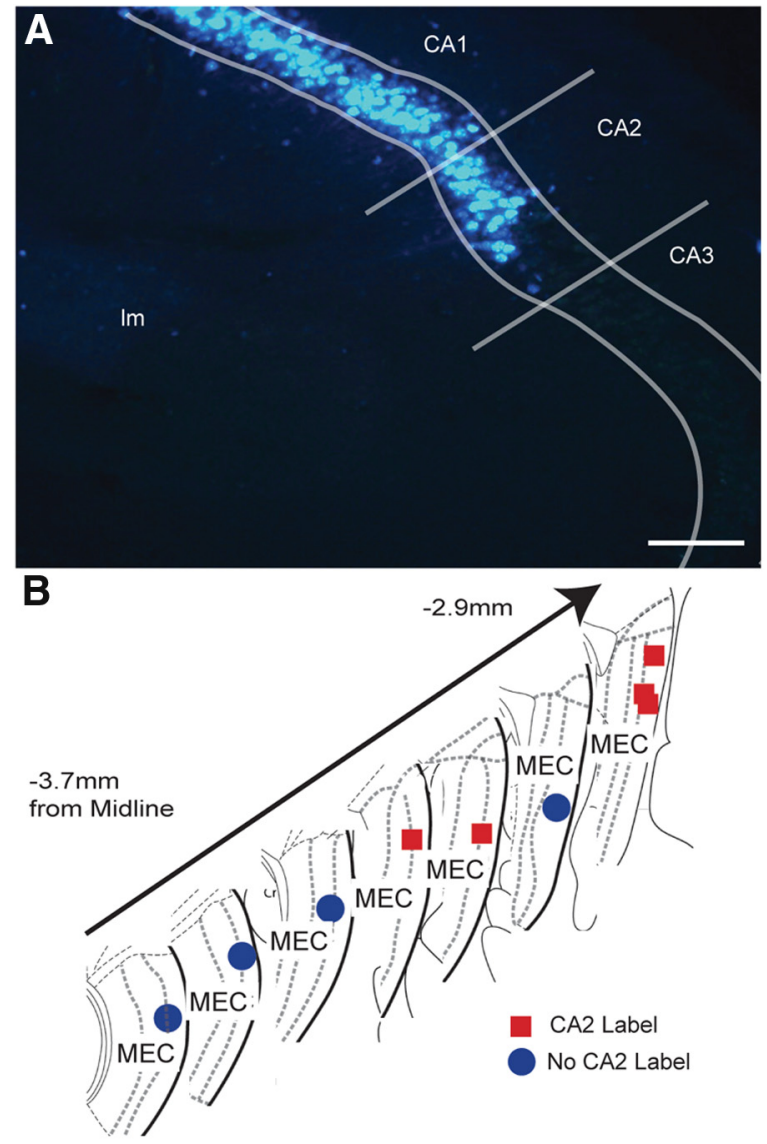

Figure 6. Retrograde labeling in CA2 and CA1 following injection of Fast Blue into MEC. $A$, Labeled neurons were observed in CA2 and CA1 following injection of Fast Blue into the superficial layers of MEC. $B$, Injection sites closer to the medial border (red squares) produced label in CA2, while more laterally and ventrally positioned injections (blue dots) did not. Scale bar, 100 $\mu \mathrm{m}$. Im, Stratum moleculare. 


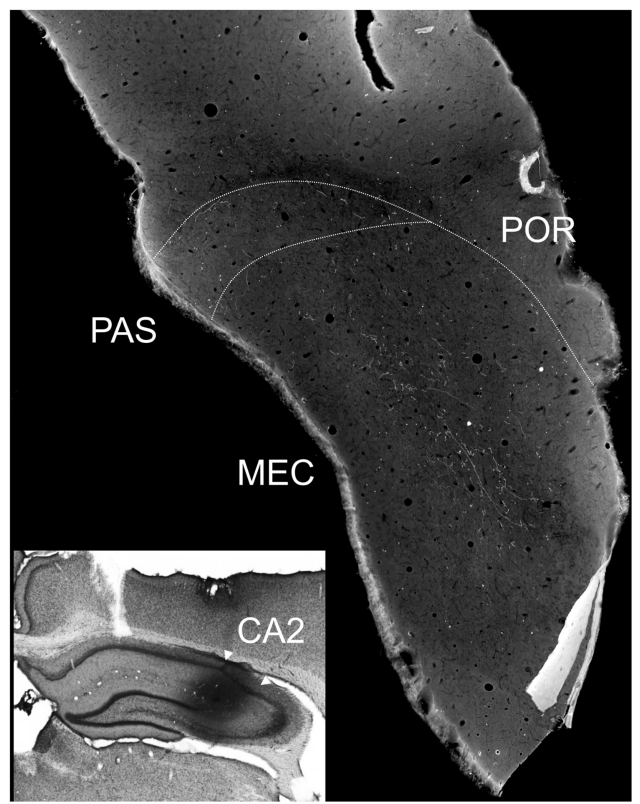

Figure 7. CA2 projects to the dorsal caudal MEC in rats. The figure shows a dark-field image of a coronal section of MEC ipsilateral to the injection of the anterograde tracer biotinylated dextran amine into the dorsal CA2 region (inset). Many labeled axons were observed along the layer II/III border in this posterior section but not in more anterior sections. PAS, Parasubiculum; POR, postrhinal cortex.

such as that for Purkinje cell protein 4, demarcate a slightly larger domain. Even when using this traditional, more conservative delineation, the vast majority of rabies-positive neurons were clearly located inside CA2. In extremely rare cases where a cell fell on a predetermined boundary, in CA2 or elsewhere, the cell was classified based on distinguishing morphological characteristics or whether it closely grouped with cells that more definitively fell within the boundaries.

We chose to focus on RFP-labeled virus because it produced the brightest label of the three fluorophores. We only counted neurons that had both a clearly labeled cell body and processes. The overall number of labeled cells (Table 2, bottom) varied between the different mouse lines in accordance with the variability of TVAG density; injected EC $\times$ TVAG-5 and EC $\times$ TVAG-7 animals showed thousands of labeled cells while the sparser EC $\times$ TVAG-4 animals showed only hundreds, but the ratios of inputs were approximately similar. Overall, the vast majority of labeled neurons (96\%) were confined to the hippocampal region. Major inputs included layer III of MEC (MEC-LIII), layer V of MEC, parasubiculum, presubiculum, and CA2, which all consistently contributed $>10 \%$ of the total label (Table 2; Fig. 8). Together, these data indicate that MEC-LII receives input from a relatively restricted set of brain areas, including the strong and previously unknown input from the CA2 region of the hippocampus.

\section{Discussion}

Monosynaptic inputs to the projection neurons of MEC-LII were mapped using a transgenically targeted viral tracing approach. More than $65 \%$ of MEC-LII neurons are stellate cells (Gatome et al., 2010), and a similar percentage has been identified as grid cells (Sargolini et al., 2006; Boccara et al., 2010). This, together with the results of intracellular in vivo recordings (Burgalossi et al., 2011; Domnisoru et al., 2013; Schmidt-Hieber and Hausser, 2013), strongly argue in favor of the assertion that the majority of grid cells are stellate cells, though the other class of LII projection neurons, the pyramidal cells, might be grid cells as well. MEC-LII stellate cells have biophysical properties that clearly differentiate them from pyramidal cells. These properties include high input resistance, prominent sag potential, strong $I_{\mathrm{h}}$ current (Giocomo et al., 2007; Canto and Witter, 2012), and membrane potential oscillations in the $4-12 \mathrm{~Hz}$ theta range (Klink and Alonso, 1993). These properties have been hypothesized to be related to the specific firing properties of grid cells, such as the sizes and distances between firing fields (Giocomo and Hasselmo, 2008; Giocomo et al., 2011). However, it is just as likely that spatial receptive fields of grid cells result from the interactions between hippocampal input and the local layer II network (Kropff and Treves, 2008; Bonnevie et al., 2013; Couey et al., 2013). Taken in this light, the inputs described here may thus be required for MEC stellate cells to exhibit grid-like receptive fields.

One of the transgenic crosses expresses appreciable amounts of TVA and $G$ in the presubiculum and parasubiculum as well. It is thus conceivable that the virus could leak into these regions in those crosses. However, injections directly into these regions (Fig. 5) yielded results quite distinct from those obtained by injections into MEC (e.g., we did not see transport to CA2), and the number of transgenic neurons in other parts of $\mathrm{EC}$ is quite negligible in all of the crosses, so it is reasonable to assume that our results specifically reflect the monosynaptic inputs to MEC-LII neurons.

No anatomical technique is perfectly quantitative. Cell fills and tracer injections involve diffusion of a bolus of label, and evoked potentials are complicated by an inability to determine the precise geometry and extent of the stimulation or strength of the individual synaptic connections. However, a case can be made that this viral approach is at least ratiometric (Marshel et al., 2010). It is generally assumed that rabies virus does not distin-
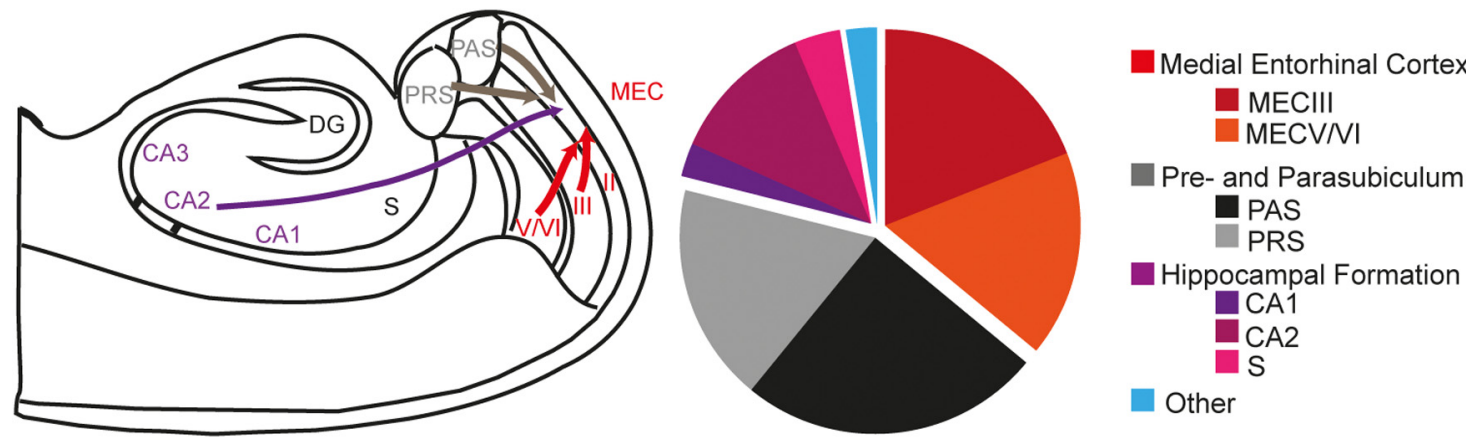

Figure 8. Overview of the major inputs to MEC-LII. Major inputs ( $>10 \%$ of the overall total) are illustrated in the schematic on the left with the thickness of the lines indicating the relative strength of the projection. The pie chart on the right gives the percentage of overall label by gross anatomical area. PAS, Parasubiculum; PRS, presubiculum; $S$, subiculum. 
guish between presynaptic cell types by activity level, identity, or size (Kelly and Strick, 2000; Callaway, 2008; Ugolini, 2011). If so, it logically follows that rabies-dependent monosynaptic label should reflect the number of inputs, if not their synaptic strength. The considerable viral amplification of signal also distinguishes this technique from traditional techniques, which fall off in intensity away from the injection site, and thereby often miss minor or distal inputs. It is likely this property of the system that enabled us to obtain our principal result of identifying a novel major projection from hippocampal area CA2 to MEC-LII. Our quantitative description of the monosynaptic inputs to MEC-LII neurons largely agrees with what others have found (Kerr et al., 2007), but also extends it in interesting ways. Our results show that the majority of inputs arise from within the hippocampal region, with only sparse inputs from outside the region. The most prominent inputs arise from the parasubiculum, presubiculum, all layers of MEC, and the CA2 region. The amygdala complex, medial septum, lateral EC, subiculum, CA1, postrhinal cortex, $\mathrm{V} 2$, and retrosplenial cortex all contribute relatively minor inputs by this method. These minor inputs may disproportionately alter the firing of cells in MEC-LII, especially the medial septum (Brandon et al., 2011; Koenig et al., 2011), but determining this requires subsequent electrophysiological investigations.

Nevertheless, the demonstration of the previously unknown major excitatory input from CA2 has important functional significance. The CA2 region of the hippocampus has historically been considered merely a transition zone between CA 3 and CA1 (or has otherwise been ignored entirely), although it was generally agreed that CA2 differed from CA3 in not receiving mossy fiber input from the dentate gyrus (Woodhams et al., 1993). Several recent studies have shown that this region possesses unique anatomical and physiological properties, making a re-evaluation of the region mandatory. First, unlike CA3, which receives input only from MEC-LII, and CA1, which receives input only from MEC-LIII, CA2 receives strong inputs from both MEC-LIII and MEC-LII (Chevaleyre and Siegelbaum, 2010). Second, CA2 neurons strongly drive CA1 neurons, the output neurons of the hippocampus. Third, CA2 neurons are only weakly driven by CA3 neurons, and these synapses do not undergo normal long-term potentiation, whereas entorhinal input leads to strong excitation (Zhao et al., 2007; Chevaleyre and Siegelbaum, 2010). Finally, in vivo stimulation of the EC leads to activation in CA2 before either CA3 or CA1 (Bartesaghi and Gessi, 2004; Bartesaghi et al., 2006). Our data add a novel return connection from CA2 to MEC-LII, indicating that unlike the rest of the CA fields, MEC-LII and CA2 are reciprocally connected and thus form a novel "short-circuit" of the entorhinal-hippocampal loop. In conjunction with the work cited above, our results help elevate CA2 from an almost universally ignored structure to a potential "gatekeeper" peculiarly well suited to coordinating hippocampal output with its major inputs in superficial EC. More anatomical and electrophysiological studies specifically targeting CA2 are needed to flesh out the specifics of its role in hippocampal-entorhinal function, but together these results indicate that MEC-LII acts like a hub within a specialized network, with a privileged role of the CA2 region as a direct feedback element.

The reciprocal connectivity between CA2 and MEC-LII has important implications for spatial computations. The mathematically precise firing patterns of entorhinal grid cells suggest that they form a universal path integration-based map of the environment (Hafting et al., 2005). However, path integration is susceptible to accumulating error (McNaughton et al., 2006). At a neural level, such error would result in drifting grid phases over time and ultimately an inaccurate spatial map. Hippocampal place cells are an ideal candidate for providing the required error correction (Sreenivasan and Fiete, 2011). However, the critical weakness of this model was that the only known pathway from the dorsal CA fields to the superficial layers of MEC was a polysynaptic one from CA1 through the deep layers of the EC. Since CA2 contains place cells, like the other CA fields (Martig and Mizumori, 2011), the strong direct connectivity between CA2 and the input layers of the EC bypasses this problem completely, allowing for the direct modification of grid cells by place cells.

The single property of the brain that sets it apart from other parts of the body is arguably the complexity of the connectivity of its composite cells, which makes gaining a detailed description of neuronal connectivity central to understanding how the brain works. The discovery of a major novel connection in so well studied a system as the hippocampus and associated cortices suggests it is likely that we are still missing many important pieces of the connectional puzzle throughout the brain, and highlights the promise of modern genetic techniques to reveal the cellular resolution connectivity of the CNS. This approach further allows for a detailed and unambiguous description of known (as well as previously unknown) inputs to particular cell types, which is worthwhile in and of itself as it makes the functional modeling of native neural circuits much more realistic. The present discovery of a novel input and description of known inputs to entorhinal grid cells thus clearly shows the enormous potential for molecular techniques to advance our understanding of the wiring of the brain on both fronts.

\section{References}

Bartesaghi R, Gessi T (2004) Parallel activation of field CA2 and dentate gyrus by synaptically elicited perforant path volleys. Hippocampus 14: 948-963. CrossRef Medline

Bartesaghi R, Migliore M, Gessi T (2006) Input-output relations in the entorhinal cortex-dentate-hippocampal system: evidence for a non-linear transfer of signals. Neuroscience 142:247-265. CrossRef Medline

Beed P, Bendels MH, Wiegand HF, Leibold C, Johenning FW, Schmitz D (2010) Analysis of excitatory microcircuitry in the medial entorhinal cortex reveals cell-type-specific differences. Neuron 68:1059-1066. CrossRef Medline

Boccara CN, Sargolini F, Thoresen VH, Solstad T, Witter MP, Moser EI, Moser MB (2010) Grid cells in pre- and parasubiculum. Nat Neurosci 13:987-994. CrossRef Medline

Bonnevie T, Dunn B, Fyhn M, Hafting T, Derdikman D, Kubie JL, Roudi Y, Moser EI, Moser MB (2013) Grid cells require excitatory drive from the hippocampus. Nat Neurosci 16:309-317. CrossRef Medline

Brandon MP, Bogaard AR, Libby CP, Connerney MA, Gupta K, Hasselmo ME (2011) Reduction of theta rhythm dissociates grid cell spatial periodicity from directional tuning. Science 332:595-599. CrossRef Medline

Burgalossi A, Herfst L, von Heimendahl M, Förste H, Haskic K, Schmidt M, Brecht M (2011) Microcircuits of functionally identified neurons in the rat medial entorhinal cortex. Neuron 70:773-786. CrossRef Medline

Callaway EM (2008) Transneuronal circuit tracing with neurotropic viruses. Curr Opin Neurobiol 18:617-623. CrossRef Medline

Canto CB, Witter MP (2012) Cellular properties of principal neurons in the rat entorhinal cortex. II. The medial entorhinal cortex. Hippocampus 22:1277-1299. CrossRef Medline

Cenquizca LA, Swanson LW (2007) Spatial organization of direct hippocampal field CA1 axonal projections to the rest of the cerebral cortex. Brain Res Rev 56:1-26. CrossRef Medline

Chevaleyre V, Siegelbaum SA (2010) Strong CA2 pyramidal neuron synapses define a powerful disynaptic cortico-hippocampal loop. Neuron 66:560-572. CrossRef Medline

Couey JJ, Witoelar A, Zhang SJ, Zheng K, Ye J, Dunn B, Czajkowski R, Moser MB, Moser EI, Roudi Y, Witter MP (2013) Recurrent inhibitory circuitry as a mechanism for grid formation. Nat Neurosci 16:318-324. CrossRef Medline 
Domnisoru C, Kinkhabwala AA, Tank DW (2013) Membrane potential dynamics of grid cells. Nature 495:199-204. CrossRef Medline

Feiden W, Kaiser E, Gerhard L, Dahme E, Gylstorff B, Wandeler A, Ehrensberger F (1988) Immunohistochemical staining of rabies virus antigen with monoclonal and ploycolocal antibodies in parafin tissue sections. Zentralbl Veterinarmed B 35:247-255. Medline

Gatome CW, Slomianka L, Lipp HP, Amrein I (2010) Number estimates of neuronal phenotypes in layer II of the medial entorhinal cortex of rat and mouse. Neuroscience 170:156-165. CrossRef Medline

Giocomo LM, Hasselmo ME (2008) Time constants of h current in layer II stellate cells differ along the dorsal to ventral axis of medial entorhinal cortex. J Neurosci 28:9414-9425. CrossRef Medline

Giocomo LM, Zilli EA, Fransén E, Hasselmo ME (2007) Temporal frequency of subthreshold oscillations scales with entorhinal grid cell field spacing. Science 315:1719-1722. CrossRef Medline

Giocomo LM, Hussaini SA, Zheng F, Kandel ER, Moser MB, Moser EI (2011) Grid cells use HCN1 channels for spatial scaling. Cell 147: 1159-1170. CrossRef Medline

Hafting T, Fyhn M, Molden S, Moser MB, Moser EI (2005) Microstructure of a spatial map in the entorhinal cortex. Nature 436:801-806. CrossRef Medline

Hama H, Kurokawa H, Kawano H, Ando R, Shimogori T, Noda H, Fukami K, Sakaue-Sawano A, Miyawaki A (2011) Scale: a chemical approach for fluorescence imaging and reconstruction of transparent mouse brain. Nat Neurosci 14:1481-1488. CrossRef Medline

Jones BF, Witter MP (2007) Cingulate cortex projections to the parahippocampal region and hippocampal formation in the rat. Hippocampus 17:957-976. CrossRef Medline

Kelly RM, Strick PL (2000) Rabies as a transneuronal tracer of circuits in the central nervous system. J Neurosci Methods 103:63-71. CrossRef Medline

Kerr KM, Agster KL, Furtak SC, Burwell RD (2007) Functional neuroanatomy of the parahippocampal region: the lateral and medial entorhinal areas. Hippocampus 17:697-708. CrossRef Medline

Klink R, Alonso A (1993) Ionic mechanisms for the subthreshold oscillations and differential electroresponsiveness of medial entorhinal cortex layer II neurons. J Neurophysiol 70:144-157. Medline

Koenig J, Linder AN, Leutgeb JK, Leutgeb S (2011) The spatial periodicity of grid cells is not sustained during reduced theta oscillations. Science 332: 592-595. CrossRef Medline

Kononenko NL, Witter MP (2012) Presubiculum layer III conveys retrosplenial input to the medial entorhinal cortex. Hippocampus 22:881-895. CrossRef Medline

Kropff E, Treves A (2008) The emergence of grid cells: intelligent design or just adaptation? Hippocampus 18:1256-1269. CrossRef Medline

Lorente de Nó R (1933) Studies on the structure of the cerebral cortex. J für Psychologie und Neurologie 45:26-438.

Lorente de Nó R (1934) Studies on the structure of the cerebral cortex. II. Continuation of the study of the ammonic system. J für Psychologie und Neurologie 46:113-177.

Mansuy IM, Bujard H (2000) Tetracycline-regulated gene expression in the brain. Curr Opin Neurobiol 10:593-596. CrossRef Medline

Marshel JH, Mori T, Nielsen KJ, Callaway EM (2010) Targeting single neuronal networks for gene expression and cell labeling in vivo. Neuron 67: 562-574. CrossRef Medline

Martig AK, Mizumori SJ (2011) Ventral tegmental area disruption selectively affects CA1/CA2 but not CA3 place fields during a differential reward working memory task. Hippocampus 21:172-184. CrossRef Medline

McNaughton BL, Battaglia FP, Jensen O, Moser EI, Moser MB (2006) Path integration and the neural basis of the 'cognitive map'. Nat Rev Neurosci 7:663-678. CrossRef Medline

O'Keefe J (1976) Place units in the hippocampus of the freely moving rat. Exp Neurol 51:78-109. CrossRef Medline

Paxinos G, Franklin KBJ (2001) The mouse brain in stereotaxic coordinates, 2nd edition. London: Academic.
Paxinos G, Watson C (2007) The rat brain in stereotaxic coordinates, 6th edition. Amsterdam: Elsevier.

Sargolini F, Fyhn M, Hafting T, McNaughton BL, Witter MP, Moser MB, Moser EI (2006) Conjunctive representation of position, direction, and velocity in entorhinal cortex. Science 312:758-762. CrossRef Medline

Schmidt-Hieber C, Häusser M (2013) Cellular mechanisms of spatial navigation in the medial entorhinal cortex. Nat Neurosci 16:325-331. CrossRef Medline

Shaner NC, Lin MZ, McKeown MR, Steinbach PA, Hazelwood KL, Davidson MW, Tsien RY (2008) Improving the photostability of bright monomeric orange and red fluorescent proteins. Nat Methods 5:545-551. CrossRef Medline

Solstad T, Boccara CN, Kropff E, Moser MB, Moser EI (2008) Representation of geometric borders in the entorhinal cortex. Science 322: 1865-1868. CrossRef Medline

Sreenivasan S, Fiete I (2011) Grid cells generate an analog error-correcting code for singularly precise neural computation. Nat Neurosci 14:13301337. CrossRef Medline

Subach OM, Gundorov IS, Yoshimura M, Subach FV, Zhang J, Grüenwald D, Souslova EA, Chudakov DM, Verkhusha VV (2008) Conversion of red fluorescent protein into a bright blue probe. Chem Biol 15:1116-1124. CrossRef Medline

Tamamaki N, Nojyo Y (1993) Projection of the entorhinal layer II neurons in the rat as revealed by intracellular pressure-injection of neurobiotin. Hippocampus 3:471-480. CrossRef Medline

Taube JS, Muller RU, Ranck JB Jr (1990) Head-direction cells recorded from the postsubiculum in freely moving rats. I. Description and quantitative analysis. J Neurosci 10:420-435. Medline

Ugolini G (2011) Rabies virus as a transneuronal tracer of neuronal connections. Adv Virus Res 79:165-202. CrossRef Medline

van Groen T, Wyss JM (1990) The connections of presubiculum and parasubiculum in the rat. Brain Res 518:227-243. CrossRef Medline

van Haeften T, Baks-te-Bulte L, Goede PH, Wouterlood FG, Witter MP (2003) Morphological and numerical analysis of synaptic interactions between neurons in deep and superficial layers of the entorhinal cortex of the rat. Hippocampus 13:943-952. CrossRef Medline

van Strien NM, Cappaert NL, Witter MP (2009) The anatomy of memory: an interactive overview of the parahippocampal-hippocampal network. Nat Rev Neurosci 10:272-282. CrossRef Medline

Weible AP, Schwarcz L, Wickersham IR, Deblander L, Wu H, Callaway EM, Seung HS, Kentros CG (2010) Transgenic targeting of recombinant rabies virus reveals monosynaptic connectivity of specific neurons. J Neurosci 30:16509-16513. CrossRef Medline

Wickersham IR, Finke S, Conzelmann KK, Callaway EM (2007a) Retrograde neuronal tracing with a deletion-mutant rabies virus. Nat Methods 4:47-49. CrossRef Medline

Wickersham IR, Lyon DC, Barnard RJ, Mori T, Finke S, Conzelmann KK, Young JA, Callaway EM (2007b) Monosynaptic restriction of transsynaptic tracing from single, genetically targeted neurons. Neuron 53:639-647. CrossRef Medline

Wickersham IR, Sullivan HA, Seung HS (2010) Production of glycoproteindeleted rabies viruses for monosynaptic tracing and high-level gene expression in neurons. Nat Protoc 5:595-606. CrossRef Medline

Witter MP (2012) Hippocampus. In: The mouse nervous system (Watson C, Paxinos G, Puelles L, eds), pp 112-138. Amsterdam: Academic.

Woodhams PL, Celio MR, Ulfig N, Witter MP (1993) Morphological and functional correlates of borders in the entorhinal cortex and hippocampus. Hippocampus 3:303-311. Medline

Yasuda M, Mayford MR (2006) CaMKII activation in the entorhinal cortex disrupts previously encoded spatial memory. Neuron 50:309-318. CrossRef Medline

Zhao M, Choi YS, Obrietan K, Dudek SM (2007) Synaptic plasticity (and the lack thereof) in hippocampal CA2 neurons. J Neurosci 27:1202512032. CrossRef Medline 